\title{
POLITICAL PARTICIPATION OF BORDER COMMUNITIES AT SAJINGAN BESAR IN ELECTION OF REPRESENTATIVES AREA
}

\author{
Elyta $^{1}$ dan Zulkarnaen ${ }^{2}$ \\ ${ }^{1,2}$ Faculty of social and Political Sciences of Tanjungpura University Pontianak \\ Prof Dr. H. Hadari Nawawi Street, Pontianak City \\ Contac Person: 081352183920 \\ E-mail:elyta79@yahoo.com
}

\begin{abstract}
ABSTRAK. Masyarakat Perbatasan di Kecamatan Sajingan Besar belum antusias dalam melangsungkan pemilu Dewan Perwakilan Rakyat Daerah Kabupaten Sambas tahun 2014 yang dibuktikan dengan banyaknya selisih jumlah antara jumlah pemilih dan jumlah pengguna hak pilih dalam menyalurkan suaranya, padahal pengguna hak pilih dalam jumlah suara sah sangat signifikan. Hasil penelitian menunjukkan bahwa terdapat bentuk partisipasi politik masyarakat perbatasan Sajingan Besar dan dua faktor yang menyebabkan partisipasi politik yaitu faktor penghambat dan faktor pendorong. Bentuk partisipasi politik masyarakat di kecamatan Sajingan Besar saat pelaksanaan pemilu Dewan Perwakilan Rakyat Daerah Kabupaten Sambas 2014 termasuk pada kelompok aktifitas pemilihan, yang hanya menyumbangkan suara untuk perolehan hasil pemilu. Faktor penghambat dalam partisipasi politik adalah (1) kesibukan aktivitas sehari-hari sebagian pekerja sehingga lebih memilih tidak terlibat dalam pelaksanaan pemilu Dewan Perwakilan Rakyat Daerah Kabupaten Sambas; 2) larangan dari pihak keluarga atas permintaan keluarga untuk ikut berpartisipasi memberikan hak pilih saat berlangsungnya pemilu Dewan Perwakilan Rakyat Daerah Kabupaten Sambas. Sedangkan faktor pendorong partisipasi politik adalah (1) rasa ingin tau masyarakat untuk dapat mengetahui tingkat kinerja dan komitmen dari pemenang pemilu Dewan Perwakilan Rakyat Daerah terpilih nantinya; 2) kesadaran politik para pemilih yang merasa memiliki kewajiban dalam melancarkan pelaksanaan pemilu Dewan Perwakilan Rakyat Daerah Kabupaten Sambas karena menyangkut kelangsungan masa depan.
\end{abstract}

Kata Kunci: partisipasi politik, pemilihan umum Dewan Perwakilan Rakyat Daerah, faktor penghambat, faktor pendorong

ABSTRACT. The community Borders the District of Sajingan not been enthusiastic in carry out elections of representatives Sambas Regency Area by 2014 as evidenced by the large number of difference in amount between the number of voters and the number of users voting rights in funneling his voice, even though the user voting rights in the total number of valid votes is very significant. The results showed that there are forms of political participation of border communities large and Sajingan two factors that lead to political participation that is an inhibitor of factor and the driving factor. Forms of political participation of the community in a big electoral exercise Sajingan Representatives Sambas County Area in 2014 including on election activities of the group, who only donate votes to tally election results. Restricting factors in political participation are (1) the bustle of daily activity most workers so prefer not to be involved in the implementation of the regional House of representatives election District of Sambas; 2) prohibition of the family at the request of participating families to give voting rights during the elections of representatives Sambas Regency Area. While the supporting factor of political participation is (1) a sense of wanting the public to be aware of the level of performance and commitment of the winner of the elections of the regional House of representatives elected later; 2) political consciousness of the voters who feel obliged in the launch of the implementation of the regional House of representatives election District of Sambas since it concerns the survival of the future.

Keywords: political participation, election of representatives area, restricting factors, supporting factors

\section{INTRODUCTION}

In the face of various forms of changes brought about by the reform, the public judged still not ready if in terms of quality and quantity. The society still has not been able to follow those changes. Political parties serve as a connector between the people and the Government in the policy of the State of democratic system of Government including State that will run democracy.

The changes that occur in Indonesia shows that political conditions are increasingly open.

Indonesia's political system shifts can be seen by implementing democracy in political system after the disintegration of the New Order system. Not a bit of difference in the policies that have been applied in Indonesia, including the holding of legislative elections and the presidential election. So for the survival of democracy required the participation of the community. The general election is a series and a part of the exercise of democracy. To select a leader, people can use right their voting through the legislative elections. In that occasion the people can be said to have supported the continuation of the democratic process. The selection consists of legislative elections (House of representatives, the regional representative council of representatives \& areas) and the election of the President as well as head of the Region that includes the Governor, the Regent/Mayor. 
Political participation is activity of a person or group of people to participate actively in political leadership of the country directly or indirectly have an impact on Government policy (Budiardjo, 2008:15). Thus the political participation is the active participation, either individuals or groups in phase opposition action or decision the fabrication, the main participation was active. From the experts, then political participation can be understood as the participation of citizens in the activities of the Government. Which the process will be controlled to to give effect on the wheels of Government, and with the emergence of political participation that could affect voters lives. Political participation is characterized by the involvement of community members in the elections started from the selection decision, they undertook to vote or not to vote in the elections. The reasons voters choices in putting put into five different types of approaches, namely, structural, sociological, ecological, social psychology and rational choice (Surbakti, 2007:146-147).

The meaning of the word democracy is already getting inherent in the mind of the community thereby providing impact on the political environment. In knowing how big the political participation of the community in Sajingan Besar democratically, can be seen from this form of public participation in the political sphere. The difference in the life of the community, is not a thing that is surprising. In a life there is difference in terms of opinion, thought patterns, and his way of life. Public participation is an important aspect to determine the success of the implementation of the Regional House of representatives election.

The change of democracy requires the existence of the role of the community to continue to be published and are introduced to the community with the goal of keeping the public can maximize its participation. Political behavior is applied to each individual are not all the same. Takes part actively and participate in the political environment as well as the political parties are part of political behavior. Politics is a container of community participation in the exercise of its authority and policies related to processing countries. The role of the voter in the election to determine the success of the holding of the elections. Political behavior and political participation has always had an affinity. The political consciousness of a society based on behavior and the level of political participation. The higher consciousness of the public to participate in the political sphere, then the better the democracy as well if the level of political participation of the community is low, then the lower the democracy system anyway, so it is said that the success of the democratic system depends on the level of participation by the community.
Meanings of the word democracy is increasingly embedded in the minds of people so that impact on the political environment. In knowing how big the political participation of the people in the district Sajingan democratically, it can be seen from the form of public participation in politics. The difference in people's lives, not be a matter of surprise. In a life there to the difference in terms of the opinion, the mindset and way of life. Community participation is an important aspect to determine the success of the regional council elections.

Democratic change requires the participation of the community to continue to be published and introduced to the public with the aim to enable communities to maximize participation. Political behavior are applied each individual are not all the same. Actively join and participate in the political environment as well as the political parties are part of political behavior. Politics is a means of public participation in carrying out its obligations related to the state authorities and policy processing. The role of the voters in the conduct of elections to determine the success of the election administration. Political behavior and political participation has always had a connection. Political consciousness of society based on the behavior and level of political participation. The higher the awareness of society to participate in the political field, the better for democracy as well as if the level of society's political participation is low, then the lower the democratic system, so it is said that the success of the democratic system depends on the level of community participation.

The people who live in Sajingan Besar started giving his political participate. This is shown in the form of some activities related to world politics. The community Borders the District of Sajingan Besar interested in make election house of representatives district of Sambas 2014 as evidenced by the active role of the community in funneling his voice

The Organization of the elections is a form of business in the form of legitimacy for the people against the individual and the various parties. The election is a form of democratic system embraced by Governments that applied in the country of Indonesia. Community participation in the implementation of this general election became a cornerstone of the democratic public are invited. In the election, create a society that is included in the categories and terms to choose has a role and a major influence in establishing the decision.

The authors will describe in more detail about the general election House of representatives District of Sambas Sub-district boundary for the community of Sajingan Besar. Forms of political participation of border communities reflected on the moment the continuity of society in the vote. The 
following is a table showing the number of voter data, user voting rights, as well as the number of valid and invalid votes in the election of representatives of areas by 2014 .

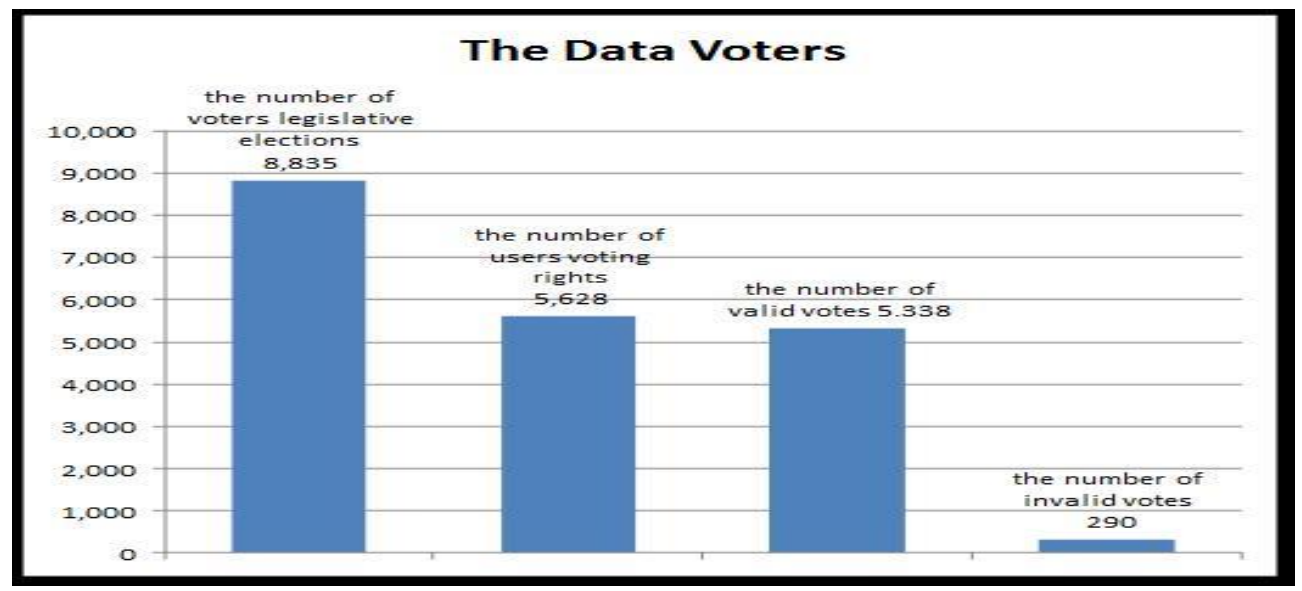

Source: Electoral Commission Province of West Kalimantan, 2014

Figure 1

Voter Data Graph, User votes, and

Number of Valid Votes Legitimate and Invalid Votes Legitimate on Parliament Election 2014 District of Sajingan Besar

From figure 1 above it, can be seen that the number of voters legislative election in Sajingan Besar at 2014 is 8,835 people. While the number of users voting right is 5,628 people. Then from the results of the recapitulation, the number of valid votes is 5,338. While for voters who voted was invalid was totaled is 290 votes. Based on the above description, it can be said that the voting rights of users related the number of voters on the election of representatives of the regional district of Sambas 2014 in Sajingan Besar is still quite low. A large number of communities that did not participate actively in taking the role of vote for legislative elections reflect that level of political participation of border communities in Sajingan Besar low enough. When the number of users voting rights acquisitionrelated legal number of votes is very significant when compared to the tally of votes invalid.

See this writer interested in researching the shape of political participation and the factor that lead the level of political participation in elections of representatives Sambas Regency Area by 2014 by the Community border in Sajingan Besar.

\section{METHOD}

The purpose of this research is to analyze the forms of political participation of border communities large and Sajingan factors that lead to political participation in elections at a time of Sajingan Besar Representatives Sambas County Area in 2014. The subject became the informant communities that have a relationship with the house of representatives election district of Sambas 2014. Data collection techniques in the form of; 1) the techniques of observation activities of the informant; 2) interview techniques regarding participants in interpreting situations and phenomena that happen and to know things from the informant in detail; 3) engineering documentation to obtain documents related to the issue that is being observed.

\section{RESULTS AND DISCUSSION Forms Of Political Participation Of The Community}

Political participation has many definitions. Political participation is the people that join in the community to vote for decisions pertaining to or influential with his life (Surbakti, 2007:98). The following advanced forms of political participation according to Huntington and Nelson: 


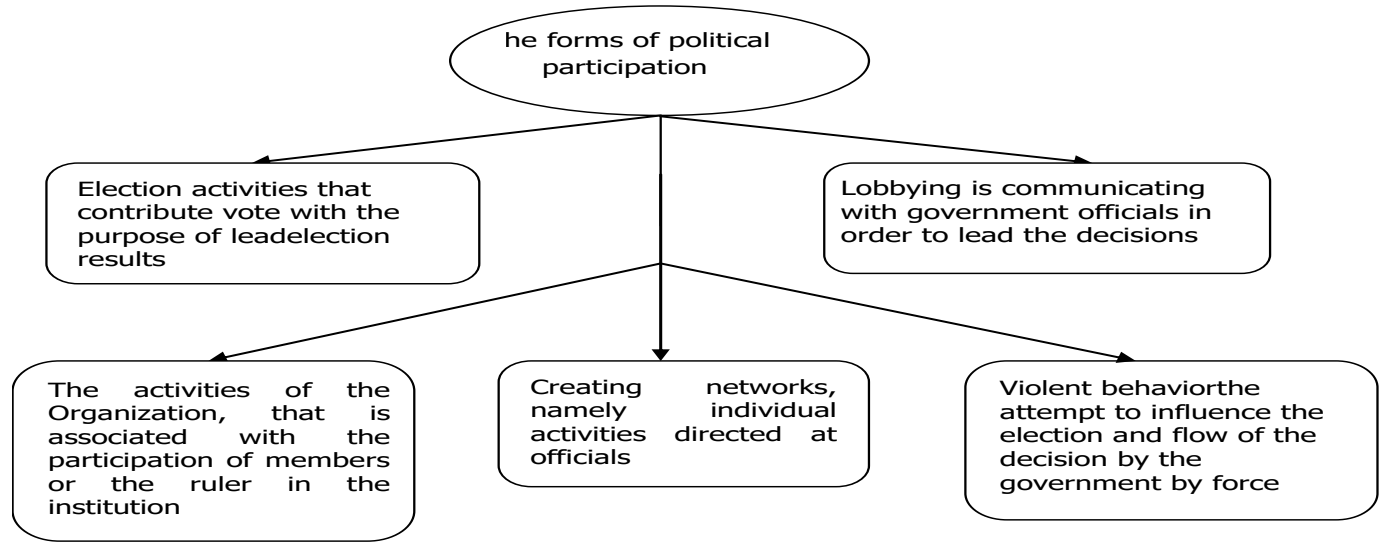

Source: Huntington dan Nelson (1994:17)

Figure 2. The forms of political participation

Hutington and Nelson said that a fifth form of political participation of the community, have different there are; 1 ) election activities, which also contributed the voice of, supporting campaign finance, involved in an election, raising support for a candidate, or acting with the aim of lead election results; 2) lobbying, is individual and group efforts to communicate with government officials and political leadership in order to exert influence on their decisions about problems that involve many people. Lobbying House members committed or committed community leaders to the Government for the sake of fast development in territory; 3) Organization of activities related to the participation as a member or the ruler in an institution with a goal as important to be able to lead government decisionmaking steps; 4) create a network, the individual activities that are directed at Government officials with the aim of obtaining avail free can be perceived by one or more persons; 5) violent behavior, the attempt to lead government decisions by force. This violence can be redirected to revamp the leadership (in the form of a coup or extermination), affects the discretion of the Government (riot or rebellion) or change all the political order (Revolution). The violence was just executed in the absence of an opportunity of participation in politics peacefully (Huntington and Nelson, 1994:17).

Based on the opinion of Hungtinton and Nelson, then forms of political participation in Major electoral exercise Sajingan Representatives Sambas County Area in 2014 including on election activities of the group, showing the people that participated and the public to follow the implementation of the regional house of representatives election district of Sambas 2014 that will influence the outcome of the election in district of Sajingan Besar. In general the community indicate that most forms of political participation one of the shape is in the form of the distribution of votes. This votes is not considered to be something familiar. Community participation forms the border of Sajingan Besar is not different form the electoral participation of representatives of the Regional District of Sambas performed other community in the region.

Forms of political participation, better known society is the implementation of the general election in the form of voting. The activities look like simple but give great lead. However, in order for its implementation can run effectively takes the initiative in planning (Marran, 2001:151). From the results of the interview against the informant proves that informants were interviewed using the right voice for waging a continuity of Regional House of representatives election District of Sambas in addition to the high sense of responsibility in carrying out the obligations of choosing leaders also be the reason. It shows that political participation to voting has been embedded.

\section{The Factors That Lead To The Level Of Political Participation Of The Community In The Implementation Of The General Election of The House Of Representatives District Of Sambas 2014 At The Border Sajingan Besar Subdistrict}

Knowledge society in running the borders of political participation is judged still exist that have not been giving political participation. Various things related to political participation is still not understood by the people of the border. The pattern of people's lives become level measurements to figure out how big the community was applying its political participation. In fact, when faced with the thought of (Roth and Wilson in Suryadi, 2007:137) that is to say a position of political participation are in the bottom layer. So it can be known that political participation play an important role. The following is an overview of the factors causing the level of 
political participation of the community in the implementation of the general election of the house of representatives district of Sambas 2014 at the border Sajingan Besar subdistrict.

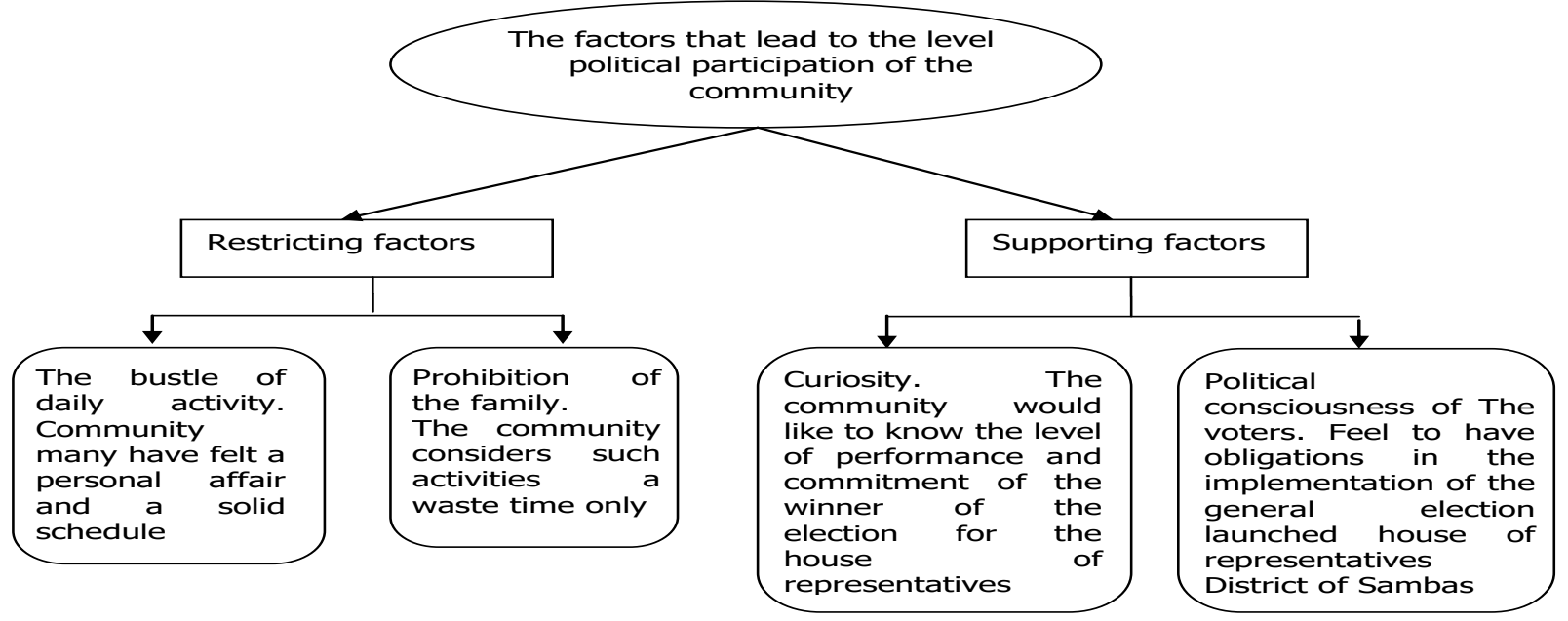

Source: prepared by researchers

Figure 3 . The factors that lead to the level political participation of the community

Based on these figure 3 can be seen, there are two factors that lead the level of political participation of the community in the implementation of the Electoral District of Sambas Sub-district boundary in 2014 Sajingan Besar as for the explanation is as follows:

Restricting factors the participation of the political community; the first restricting factors is bustle of daily activities. Community voters residing in the border district of the majority of Sajingan Besar consists of several activist groups, including students, workers who are bound or free, and others. These factors make some people not interested in following the activities of the regional House of representatives election District of Sambas as they also feel many have private affairs related to its activities. It becomes a barrier to their participation ahead of the implementation of the regional house of representatives election district of Sambas. They are more interested in continuing to work compared with having to get involved in the implementation of the regional house of representatives election district of Sambas. But the flurry of variety can actually be addressed by dividing the time and take themselves to participate in the political environment. One who has admitted working yet can run its obligations as voters linked their obligations in terms of personal to meet its obligations including has the hectic work schedule of activities in daily life. It becomes a barrier for them to participate in the implementation of the regional house of representatives election district of Sambas. They are more interested in continuing to work compared with having to get involved in the implementation of the regional House of representatives election District of Sambas

The second restricting factors is prohibition of the family. Habit to listen and meet the demand of the family can be a barrier to a person to participate in the following election of representatives Sambas Regency Area. They prefer to comply with the request of the family, even when instructed not to follow the activities of the regional House of representatives election District of Sambas in progress, then they will also stick with it. For example there are families which prohibits his son for voting because of the juice of disillusionment with the performance of the winner of the election before making it choose not to vote because it considered those activities wasting time only. From the results of the interview there is also recognition that indicates that a given sound channeling some societies, especially novice voters still unable to independently establish its decision in choosing and are still influenced by the wishes of his parents.

The fact that often occur in the field is that they still do not have sufficient understanding of world politics to determine leaders and most have only heard suggestions without proof directly. They feel pessimistic at first, but they must remain steeped in politics so as not to become a lay community on an ongoing basis, let alone the political part is also part of his life. Factors that lead the behaviour of politics; 1) socio-political environment indirectly, such as mass media, cultural and other systems; 2) direct political environment such as family, friends, class and religion; 3) how to behave that reflected the personality of the person; 4) social factors directly form situations that lead a person's wishes in carrying out political activity (Hermawan, 2001:72).

The first supporting factors is in customs, political participation, most families have an important role in encouraging the desire and purpose to set options, if the family does not agree then that individual participated in stopping his pace. The 
driving factor of political participation of the community; Fasktor penghambar pertama Curiosity. Political participation is activities conducted individual and groups to transmit his voice in the election to know the performance of leaders who will have the authority to regulate State. It can be seen that the border communities in Sajingan Besar already showing his participation in the vote at the time of implementation of the Regional House of representatives election District of Sambas. They claimed that the election was part of the activities that will take the country towards a policy, so that the public can know the performance level and the commitment of the winner of the election was elected later

The second supporting factors is the political consciousness of the voters. The level of Political consciousness of the voters in the border community of Sajingan Besar belongs. Their consciousness is formed because they feel they have a duty in the launch of implementation of the Regional House of representatives election district of Sambas. The things they do because they feel this case concerns the continuity of the future that will be faced in the future and felt that he was including a citizen of Indonesia. If the name is already registered to become voters, then it becomes a must for border communities in Sajingan Besar to vote. From the results of the interview against the informant informant interviewees proved that most of them use their vote to launch the continuity of elections Representatives Sambas Regency Area in addition to the high sense of responsibility in carrying out the obligations of choosing leaders also be the reason. It shows that political participation to voting has been embedded.

\section{CONCLUSION}

Based on the results of research undertaken researchers, it can be concluded that in the exercise of democracy required a form of political participation of the community at the time of the election of representatives of the regional district of Sambas subdistrict Sajingan Besar 2014. The political participation of the community is in the form of polling. It can be said that the level of political participation of border communities in the big pretty low because Sajingan magnitude difference between the number of voters and the voting rights of users. While the number of users voting rights acquisition-related legal number of votes is very significant when compared to the tally of votes invalid. There are two factors in political participation, namely restricting factor and the supporting factor. Restricting factors in political participation among them are (1) the bustle of daily activity because it is more interested in continuing to work compared with having to get involved in the implementation of the regional House of representatives election District of Sambas; 2) prohibition of the family due to the habit to listen and meet the demand of the family can be a barrier to a person to participate in the following election of representatives Sambas regency area. While the supporting factor of political participation is (1) a sense of wanting to know the society because the election is part of the activities that will take the country towards a policy, so that the public can know the performance level and the commitment of the winner of the election for the House of representatives of the regional elected later; 2) political consciousness of the voters who feel obliged in the launch of the implementation of the regional House of representatives election District of Sambas since this concerns the continuity of the future.

\section{SUGGESTION}

This suggestion is indicated for governments and communities to improve the level of political participation.

a. Government

In raising the level of public participation, the Government is expected to evaluate and optimize performance in leading and processing countries. It aims to restore a positive image of the Government towards the Community perspective. So, people avoid the attitude of indifferent and unconcerned in the electoral process.

b. Community

Should the community tends to be passive to participate in elections must open his eyes, to recognize the importance of participating in the elections. This is due to the existence of a link between the election and the continuity of their future through leaders who will be elected.

\section{BIBLIOGRAPHY}

Budiardjo, Miriam. 2008. DasarDasar IlmuPolitik. Jakarta: Gramedia

Hermawan, Eman. 2001. Politik Membela yang Benar. Yogyakarta: Yayasan KLIK

Huntington, S dan Nelson. 1994. Partisipasi politik di Negara berkembang. Jakarta: Rineka Cipta.

Komisi Pemilihan Umum Provinsi Kalimantan Barat tahun 2014, tentang Data Pemilih, Pengguna Hak Pilih serta Jumlah Suara Sah dan Tidak Sah Pemilu DPRD Kecamatan Sajingan Besar.

Maran, R. R. 2001. Pengantar Sosiologi Politik. Jakarta: Rineka Cipta. 
Surbakti, Ramlan. 2007. Memahami Ilmu Politik. Jakarta: PT Gramedia Widisarana.
Suryadi, Budi. 2007. Sosiologi Politik Sejarah Definisi dan Perkembangan Konsep. Yogyakarta: IRCiSoD 